\title{
A Regional Land Use Drought Index for Florida
}

\author{
Chi-Han Cheng ${ }^{1}$, Fidelia Nnadi ${ }^{2}$ and Yuei-An Liou ${ }^{3,4,5, *}$
}

Received: 13 August 2015; Accepted: 6 December 2015; Published: 18 December 2015

Academic Editors: Yaoming Ma, Takashi Oguchi, Indrajeet Chaubey, Magaly Koch and Prasad Thenkabail

1 Applied Hydrometeorological Research Institute, Nanjing University of Information Science \&

Technology, Nanjing 210044, China; herrymarry@gmail.com

2 Department of Civil, Environmental and Construction Engineering, University of Central Florida, Orlando, FL 32816, USA; Fidelia.Nnadi@ucf.edu

3 Center for Space and Remote Sensing Research, National Central University, Chung-Li District, Taoyuan 32001, Taiwan

4 Taiwan Group and Earth Observations, Zhubei City, Hsinchu County 30274, Taiwan

5 Taiwan GIS Center, Taipei 10092, Taiwan

* Correspondence: yueian@csrsr.ncu.edu.tw; Tel.: +886-3-422-7151 (ext. 57631); Fax: +886-3-425-4908

\begin{abstract}
Drought index is a useful tool to assess and respond to drought. However, current drought indices could not fully reveal land use effects and they have limitations in applications. Besides, El Niño Southern Oscillation (ENSO), strongly influences the climate of Florida. Hence, understanding ENSO patterns on a regional scale and developing a new land use drought index suitable for Florida are critical in agriculture and water resources planning and management. This paper presents a $32 \mathrm{~km}$ high resolution land use adapted drought index, which relies on five types of land uses (lake, urban, forest, wetland, and agriculture) in Florida. The land uses were obtained from National Centers for Environmental Prediction (NCEP) North American Regional Reanalysis (NARR) data from 1979 to 2002. The results showed that Bowen ratio responded to land use and could be used as an indicator to monitor drought events. Then, an innovative regional land use drought index was developed from the normalized Bowen ratio, which could reflect not only the level of severity during drought events resulting from land use effects, but also La Niña driven drought impacts. The proposed new index may help scientists answer the critical questions about drought effect on various land uses and potential feedbacks of changes in land use and land cover to climate.
\end{abstract}

Keywords: drought index; land use/cover; ENSO; North American Regional Reanalysis (NARR)

\section{Introduction}

When a large area over a period of time loses a significant amount of water without availability of replenishment, the area is said to be under drought condition [1]. During droughts, water supplies are inadequate to meet the demand of water-related systems and cause serious agriculture, hydrologic, and socio-economic damages. According to a report given by the United States FEderal Management Agency (FEMA), droughts occur almost every year across some portions of the nation (e.g., the widespread events of 1995-1996 in the southwest and southern Great Plains; 1998 in the South; 1999 in the Northeast; 2000 in the South, Mid-west, and Great Plains; 1998-2002 in the Southeast; and 2002 in the East). The report also suggested that the United States loses $\$ 6-8$ billion annually on average due to drought [2]. It is evident that there is a great interest and need in better defining, monitoring, and predicting droughts.

Drought indices generally integrate various hydrological and meteorological parameters and quantify climate anomalies in terms of intensity, duration, and spatial extent, thus easily conveying information to the diverse users [3]. In the United States, great efforts have been made to develop a variety of drought indices for water resources management, and agricultural drought monitoring 
and forecasting, including Palmer Drought Severity Index (PDSI) [4], Crop Moisture Index (CMI) [5], Standardized Precipitation Index (SPI) [6], and Surface Water Supply Index (SWSI) [7]. However, drought is a complex phenomenon that is difficult to detect and monitor due to a variety reasons: (1) it develops slowly and its onset and ending are indistinct; (2) it is not universally defined; and (3) its impact is nonstructural and often spreads over very large areas [2]. To our knowledge, there is no single global definition of drought and there are no universal drought indices. As current drought indices are calculated from climate data based on point measurements of meteorological stations, which are sparsely set up in remote areas and not uniformly distributed, their applications are subject to limitations and drawbacks. Besides, the identification and intensity of drought must be considered as factors that affect regional or national economic planning. For monitoring purpose, it is necessary to track drought from point measurements to drought developments on a regional scale.

For PDSI, potential evapotranspiration (PET) is calculated using Thornthwaite's method, which estimates evapotranspiration (ET) based on an empirical relationship between ET and temperature [8]. Nevertheless, the Thornthwaite equation does not perform well in estimating ET under various climatic conditions [9]. It is suggested that ET can consume up to $80 \%$ of rainfall according to general circulation model (GCM) simulations and has a substantial influence on drought condition, but such influence is difficult to validate due to limited observations [10,11].

The consideration of spatial variability of hydrological parameters related to soil properties, land use, and meteorological parameters, such as rainfall and temperature, is a better approximation of the hydrologic system and improves the ability to monitor drought at a much better spatial resolution [12]. In reality, parameters like land use/cover and soil properties vary greatly and are sparsely measured by ground-based instruments. As human activities affect land use characteristics, which impact the distribution of ecosystem, land-air energy balance (latent and sensible heat), and mass fluxes (e.g., water vapor, trace gases, and particulates), contrasting land use patterns to induce convection and circulation that affect cloud formation and precipitation. Hence, developing a drought index from water balance is not enough to reflect the level of severity in drought events resulting from land use effects. The simplistic approaches based on measures of rainfall deficiency, such as SPI, National Rainfall Index (RI), Rainfall Anomaly Index (RAI), and Bhalme and Mooly Drought Index (BMDI), were shown to underestimate the severity of drought [13]. The more complex drought indices, PDSI and CMI, which are based on water balance model, assumed that parameters such as land use/land cover, and soil properties are uniform over the entire climatic zone $\left(7000-100,000 \mathrm{~km}^{2}\right)$ [12]. For SWSI, it does not directly consider the other elements of hydrological cycles that are critical for drought monitoring, such as evaporation, soil moisture, and land use characteristics [14]. Hence, critical gaps in drought monitoring are about drought effect on various land uses and potential feedbacks of changes in land use and land cover to climate.

Data assimilation techniques, integration of virtues of observations, and modeling by fusing them together, have been studied and used for decades in meteorological and oceanic applications [15]. North American Regional Reanalysis (NARR) data, which include model-based four-dimensional data assimilation procedures, may provide a great possibility for more accurate evaluation of interactions of the land surface-atmosphere and could be used for conquering the limitations of current drought indices. The objective of this study is to develop a Regional Land use adapted Drought Index (RLDI) suitable for Florida based on the NARR dataset. Improvements in current drought monitoring and forecasting techniques will allow better preparation, lead to better management practices, and mitigate the vulnerability of society to drought and its subsequent impacts.

\section{Dataset}

This study employs the NARR dataset developed at the Environmental Modeling Center (EMC) of the National Centers for Environmental Prediction (NCEP). This dataset is based on the April 2003 frozen version of the operational Eta Model and its associated Eta Data Assimilation System (EDAS), and uses many observed quantities in its data assimilation scheme, including gridded analysis of 
rain gauges precipitation over the continental United States (CONUS), Mexico, and Canada [16]. Hence, this regional reanalysis is produced at high spatial and temporal resolutions (32-km, 45-layer, 3-hourly) and spans a period of 25 years from October 1978 to December 2003. The strengths of NARR include its assimilation of precipitation observations and its high spatial-temporal resolution. The assimilation constrains the diurnal cycle of precipitation, which is poorly quantified by current convection schemes, and latent and sensible heat flux partitioning, which is often poorly predicted by land surface models [17]. Full details on the NARR products can be found online at http://www.emc.ncep.noaa.gov/mmb/rreanl/.

The EDAS is successful with downstream effects, including two-way interaction between precipitation and improved land-surface model [18]. Mitchell et al. [19] demonstrated significant regional improvements in a number of variables when using precipitation assimilation over the CONUS. Therefore, NARR outputs have been used to: (1) evaluate the performance of global and regional climate model outputs [20,21]; (2) study the pattern of major hydro-climatic variability (e.g., precipitation recycling) [22]; and (3) assess the impacts of land use and land cover change [23]. In this study, the 24-year monthly averages of soil moisture, runoff, actual surface evaporation and precipitation, latent heat, sensible heat and surface temperature from 1979 through 2002 of the NARR data were utilized.

\section{Study Area}

Florida climate is humid and subtropical with rainy wet season extending from May through October. Most areas in Florida receive at least $1270 \mathrm{~mm}$ of rainfall annually. The annual precipitation varies very much annually as floods may occur in one year, but followed by drought in the next year. The long-term annual mean temperature is $22.4{ }^{\circ} \mathrm{C}$ based on historical records of a weather station located in Kissimmee, Florida (Southeast Regional Climate Center, http://www.dnr.sc.gov/climate/sercc).

\subsection{ENSO in Florida}

El Niño Southern Oscillation (ENSO), a global climate fluctuation, originates in the equatorial Pacific Ocean through larger-scale interaction between the ocean and atmosphere and operates on a timescale of 2-7 year [24]. ENSO has three phases: warm tropical Pacific Sea Surface Temperatures (SSTs) (El Niño), cold tropical Pacific SSTs (La Niña), and near-neutral conditions. This study used NOAA's operational definitions of El Niño and La Niña conditions based on the Oceanic Niño Index $(\mathrm{ONI})$, which is defined as the 3-running means of SST anomalies in the Niño 3.4 region $\left(5^{\circ} \mathrm{S}-5^{\circ} \mathrm{N}\right.$, $170-120^{\circ} \mathrm{W}$ ), derived from the year 1971-2000 SST climatology and considered as representing the average equatorial SST anomalies across the Pacific from about the dateline to South American (NOAA/National Weather Service). To be classified as a full-fledged El Niño or La Niña episode, the ONI must exceed +0.5 (El Niño) or -0.5 (La Niña) for at least five consecutive months. As a result, the period from 1979 to 2002 consists of 7 El Niño (1982, 1986, 1987, 1991, 1994. 1997, and 2002) and 6 La Niña events $(1984,1988,1995,1998,1999$, and 2000).

ENSO influences the climate of the southeastern U.S. coastal plain, including Florida: El Niño years tend to be cooler and wetter, and La Niña years appear to be warmer and drier than normal in Fall through Spring with the strongest effect in Winter [25-27]. During El Niño, additional rain could lead to greater net precipitation and ground water recharge because it occurs during winter at a time when evaporation is low [28]. In contrast, La Niña events keep the polar jet stream and extra-tropical systems north of Florida with a dry condition [29]. The low monthly precipitation increases the severity and frequency of droughts and wildfires during La Niña events. Consequently, in recent decades major droughts occurred in Florida during the early 1970s, early 1980s, 1985, 1988-1990 and 1999-2001 periods.

ENSO have great impacts on Florida's agriculture. Agriculture is one of the most important economic resources in Florida. Florida crop yield contributed $63 \%$ of winter vegetables in the U.S. with a revenue of $\$ 1.48$ billion [30] in 1995-1996. Studies have shown that Florida vegetable 
yields are correlated with ENSO-related Pacific SST in winter, summer, and fall quarters [31,32]. Drought-induced wildfire is also a serious problem in Florida. For example, rapid emergence of drought following a strong El Niño event in 1998 resulted in drought-induced wildfires in Florida and statistics show that 25,137 fires burned 1.5 million acres between 1998 and 2002 (Florida Division of Forestry, undated (a)). Therefore, understanding the local ENSO patterns on regional scale and developing a new land use drought index in Florida are critical for agriculture and water resources managements.

\subsection{The Selected Areas}

In this study, five different land uses data from 1992 National Land Cover Dataset in six $32 \times 32 \mathrm{~km}$ regional study areas were selected for Florida's different climatic zones as shown in Figure 1. These land uses include urban, forest, and agriculture in northeast Florida, and lake, wetland, and agriculture in South Florida (Figure 2). In northeast Florida, the climate is somewhat cooler and receives abundant precipitation between 1000 and $1500 \mathrm{~mm}$ annually, thus enabling the production of the specialized crops. Therefore, a regional agriculture land use, located in west Alachua and devoted to forage, hay production, and silage corn, was selected for studying the energy budget. Moreover, the Ocala National Forest area was selected as a regional forestland use area because extensive pine plantations are relatively common in North Florida [33]. Finally, we chose urban area-Jacksonville as a study area because substantial population growth has occurred, causing Nan expansion of urban and developed land. Within 30 years, the population increased by more than 140 percent, creating larger urban areas as in Orlando, St. Petersburg, Tampa, and Jacksonville (USGS-Land Cover Trends Project: Southern Coastal Plain).

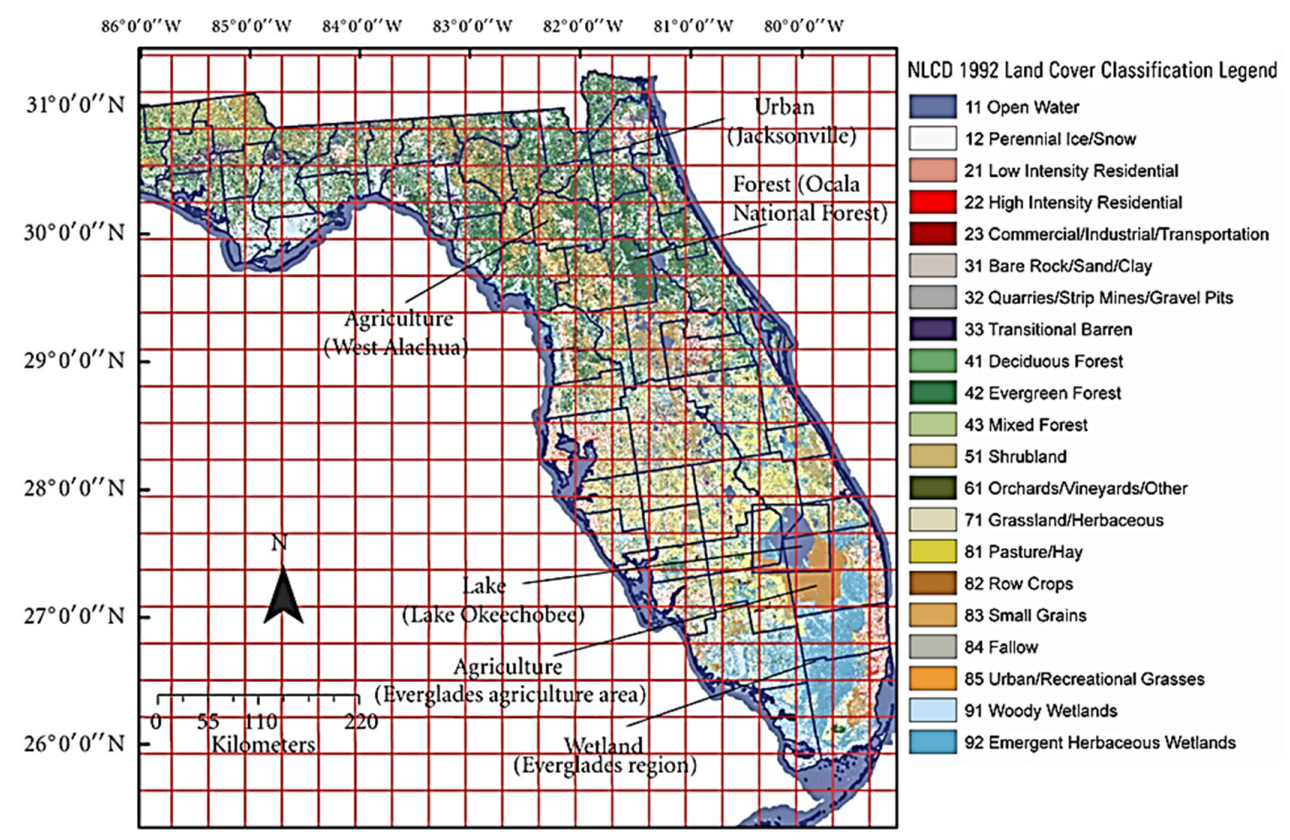

Figure 1. Six selected $32 \times 32 \mathrm{~km}^{2}$ regional study areas along with land-use/land cover from the 1992 National Land Cover Dataset. The red gridline is a $32 \times 32 \mathrm{~km}^{2}$ resolution grid from NARR Data reanalysis dataset (revised from [34]).

In South Florida, the climate is generally frost-free and subtropical and annual rainfall is about $1400 \mathrm{~mm}$. The main regional characteristics are wetland, lake, agriculture, and urban areas (Figure 1). The Everglades region is a subtropical wetland that covers much of South Florida, and comprises of over 4000 square miles stretching from Lake Okeechobee in the north to the Florida Bay in the southern end of the peninsula [35]. Hence, it was selected to represent the regional $32 \times 32 \mathrm{~km}$ grid of wetlands in south Florida. Lake Okeechobee (Figure 1) is the second largest freshwater lake 
in the U.S. and covers a surface area of 1800 square $\mathrm{km}$ with an average depth of $2.7 \mathrm{~m}$. It is a large, shallow, and eutrophic lake located in south central Florida, and frequently hit by hurricanes. As the central part of a larger interconnected aquatic ecosystem and as the major surface water body, Lake Okeechobee provides a number of societal and environmental service functions including water supply for agriculture and urban areas [36]. Therefore, investigating impacts of drought events on the Lake is very critical. Finally, the Everglades Agriculture Area (EAA), a small portion of the Everglades region consisting of artificially rich organic soil supporting a thriving agriculture industry with annual benefits around $\$ 500$ million was also considered for the study [37].

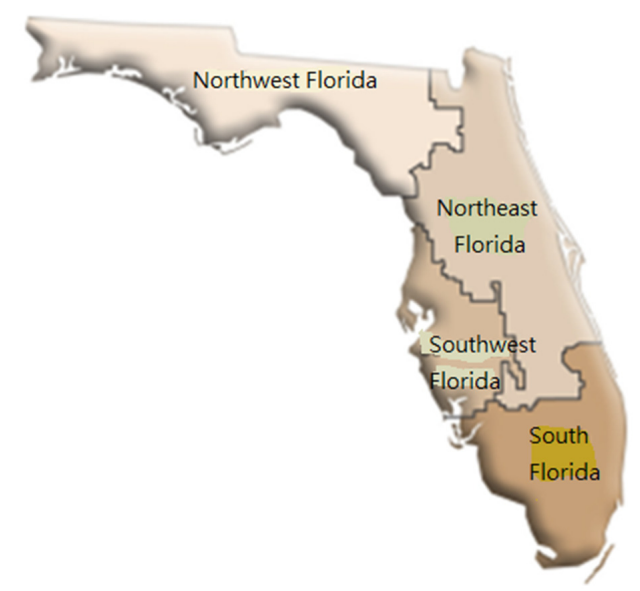

Figure 2. Map of Florida depicting the four regions of the State (revised from [34]).

By comparing land use and land cover in Figures 1 and 3 the land use changes could be monitored and detected. The regional agriculture land use, which is located in west Alachua, was changed from row crop in 1992 to pasture hay in 2001, but the other land use areas were not appreciably changed within the 10-year period. Thus, we assumed land use types of the selected areas did not change from 1979 to 2002.

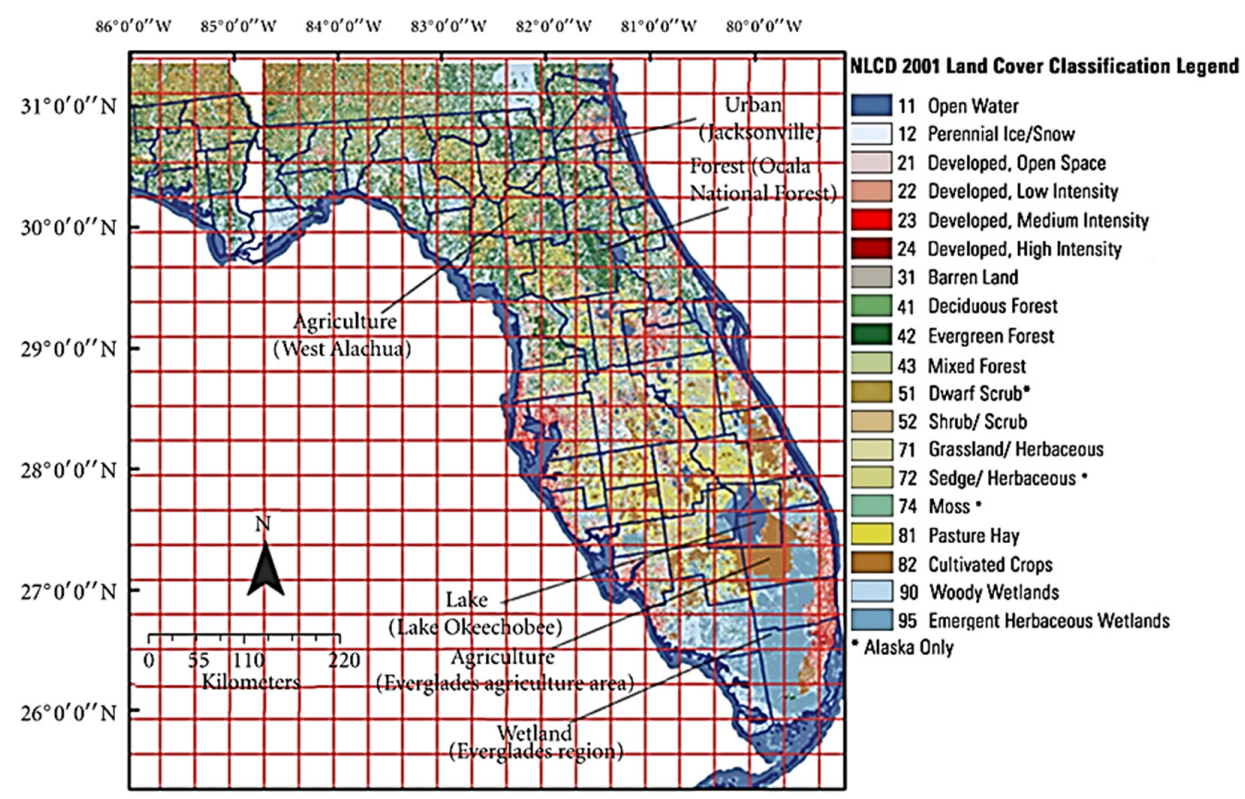

Figure 3. Six selected $32 \times 32 \mathrm{~km}^{2}$ regional study areas along with land-use/land cover from the 2001 National Land Cover Dataset. The red gridline is a $32 \times 32 \mathrm{~km}^{2}$ resolution grid from NARR Data reanalysis dataset (revised from [34]). 


\section{Methods}

In this study, Bowen ratio, the ratio of sensible to latent heat fluxes, was used as an indicator to monitor drought events based on the following two assumptions: (a) Bowen ratio is higher during drought events. During drought events, the partitioning of net radiation is skewed, with more heat going into the sensible heat flux and less into the latent heat flux. The increased sensible heat flux acts to heat the canopy and boundary layer; (b) Bowen ratio reflects the characteristics of land use. For example, the lake may have a lower Bowen ratio because more surface energy would be partitioned into latent heat for evaporation, while the wetland areas have a higher value due to lower evaporation. The Bowen ratio on the agriculture areas may depend on the ET and soil moisture conditions. For example, trees contain more moisture than grass and, thus, can maintain higher ET during a drought event, as more net energy would be converted into latent heat for evaporation. Hence, Bowen ratio is lower in trees than grassland areas.

A Regional Land use Drought Index (RLDI) was computed as the normalized monthly Bowen ratio of the different land use areas for both dry and wet periods:

$$
\mathrm{RLDI}=\frac{B_{m}-B_{m v}}{\sigma_{y}}
$$

where $B_{m}$ is the monthly Bowen ratio; $B_{m v}$ is the long term average of monthly Bowen ratio; and $\sigma_{y}$ is the standard deviation of monthly Bowen ratio.

\section{Result and Discussions}

\subsection{Monthly Rainfall Variations and Standardized Precipitation Index (SPI)}

The temporal and spatial rainfall distributions vary annually. Figures 4a and 5a present the time series plots of monthly rainfall of the various land use areas in both northeast and south Florida, respectively. In Northeast Florida, the monthly rainfall ranged from $0.16 \mathrm{~mm} /$ day to $12.64 \mathrm{~mm} /$ day, and from $0 \mathrm{~mm} /$ day to $15.28 \mathrm{~mm} /$ day in the south during the study period. The drought index of SPI to quantify the precipitation deficit for multiple time scales was calculated for a one-month time scale and used to identify drought events [36]. This reflects the short time soil moisture condition. Figures $4 \mathrm{~b}$ and $5 \mathrm{~b}$ present time series plots of one-month SPI in Northeast and South Florida, respectively. The figures suggest drier conditions during 1980-1982, 1984-1985, 1988-1990, and 1999-2001 due to extreme short rainfall events in winter and early spring. However, it is found that SPI had no huge differences in the various land use areas, inferring that SPI could not reflect drought impacts on different land use covers.

Rainfall (mm/day)

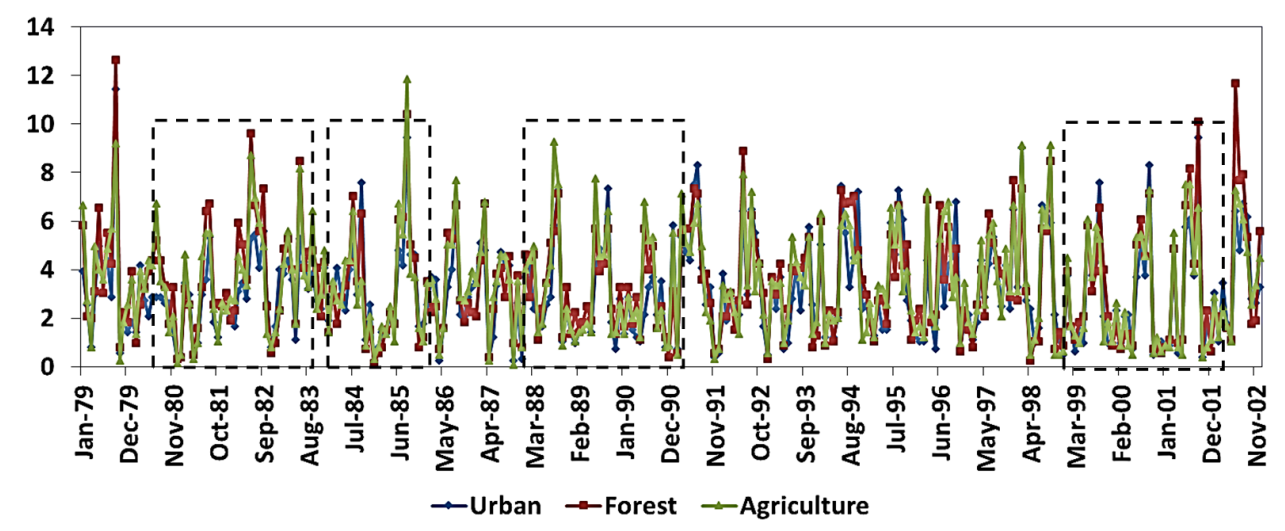

(a)

Figure 4. Cont . 


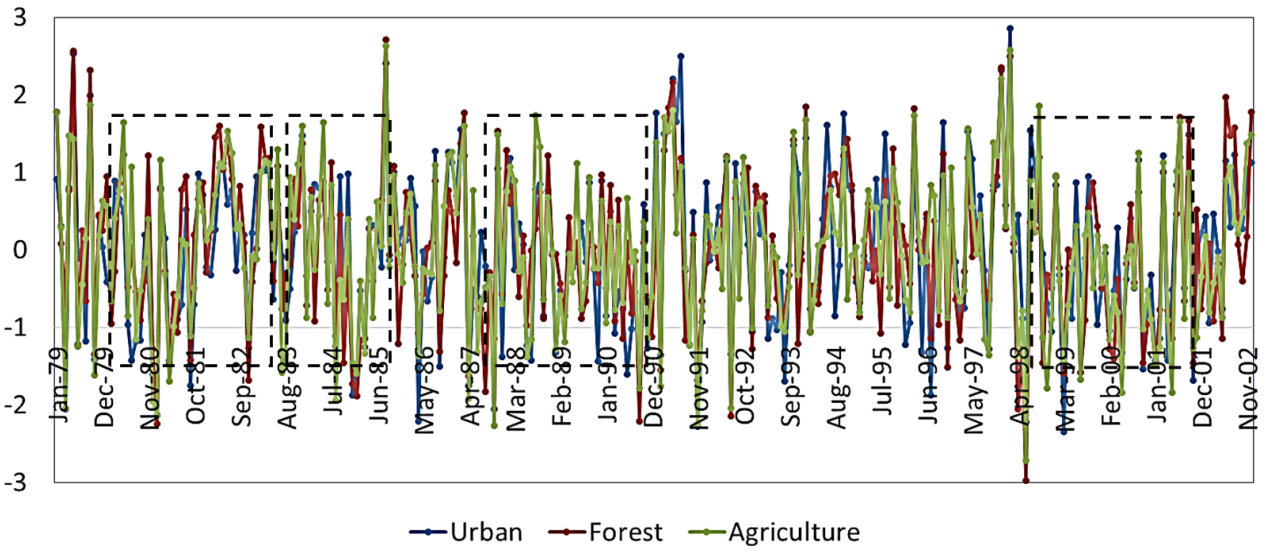

(b)

Figure 4. (a) Time series for monthly rainfall patterns for Northeast Florida; dash box areas represent drier periods; (b) Time series of Standardized Precipitation Index (SPI) for Northeast Florida; dash box areas represent drier periods.

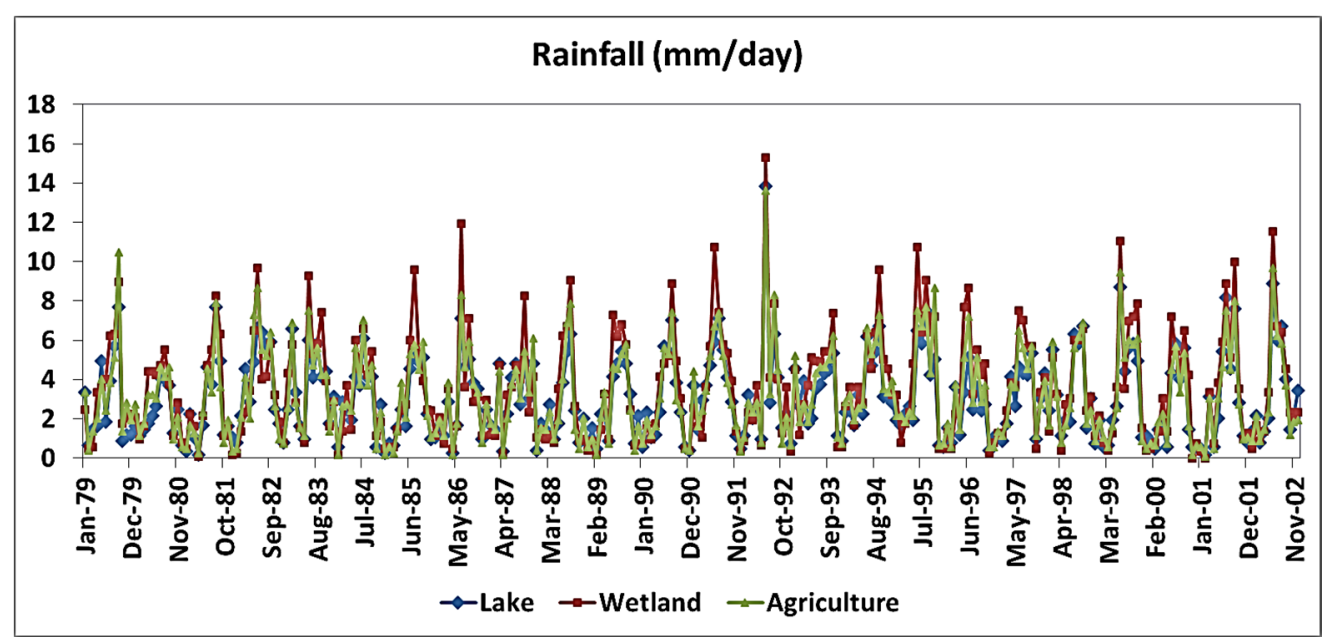

(a)

SPI

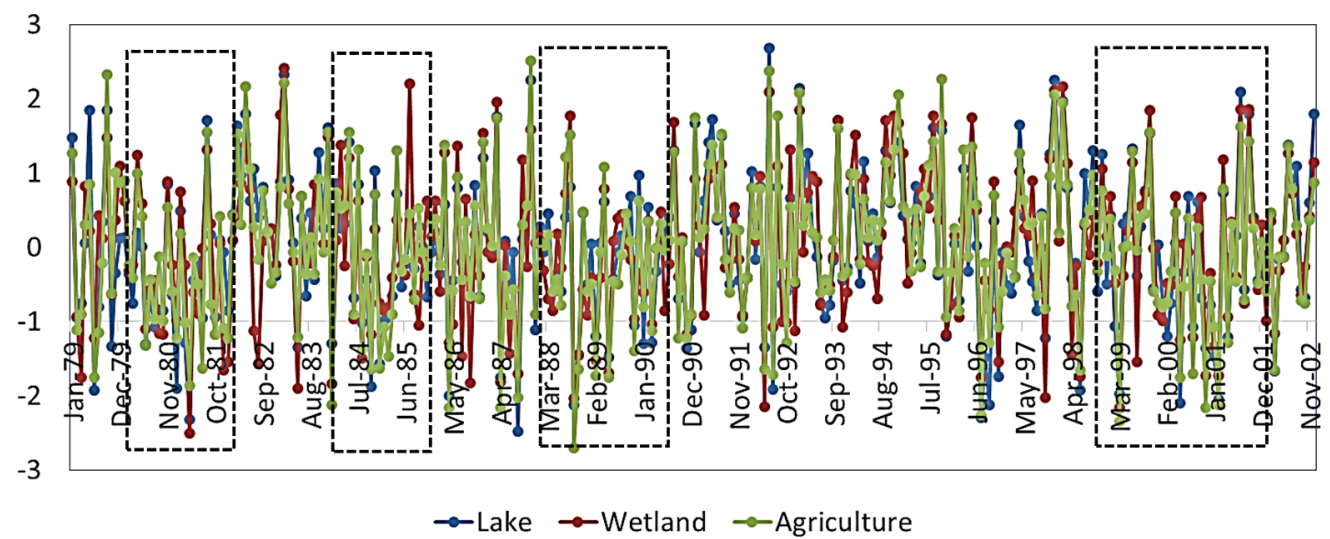

(b)

Figure 5. (a) Time series for monthly rainfall patterns for South Florida; (b) Time series of Standardized Precipitation Index (SPI) for South Florida; dash box areas represent drier periods. 


\subsection{Monthly Evaporation and Soil Moisture Variations}

In the hydrologic budget of Florida, ET is the second most important component after precipitation [38]. It is influenced by seasonal changes in climate and can vary considerably within basins with different types of vegetation or different proportions of water surface areas. Figure $6 a, b$ shows the inter-annual variations of evaporation from 1979 to 2002 for various land use areas in Northeast and South Florida, respectively. In the northeast, the monthly evaporation ranged from $1.6 \mathrm{~mm} /$ day to $4.56 \mathrm{~mm} /$ day in the urban area, $1.12 \mathrm{~mm} /$ day to $4.48 \mathrm{~mm} /$ day in the forest area, and $0.72 \mathrm{~mm} /$ day to $4.88 \mathrm{~mm} /$ day in the agriculture area. While in the south, monthly evaporation ranged from $1.2 \mathrm{~mm} /$ day to $4.4 \mathrm{~mm} /$ day in the lake area, $1.28 \mathrm{~mm} /$ day to $3.84 \mathrm{~mm} /$ day in the wetland area, and $0.4 \mathrm{~mm} /$ day to $4.8 \mathrm{~mm} /$ day in the agriculture area. During spring drought events in the northeast, the agriculture area had a lower evaporation rate in spring with values between $0.72 \mathrm{~mm} /$ day and $2.24 \mathrm{~mm} /$ day, while the urban and forest areas had higher evaporation values between $3.12 \mathrm{~mm} /$ day and $4.16 \mathrm{~mm} /$ day. In the South, the agriculture area also had lower evaporation values between $0.56 \mathrm{~mm} /$ day and $2.8 \mathrm{~mm} /$ day, while the lake and wetland areas had higher evaporation values between $1.68 \mathrm{~mm} /$ day $2.88 \mathrm{~mm} /$ day.

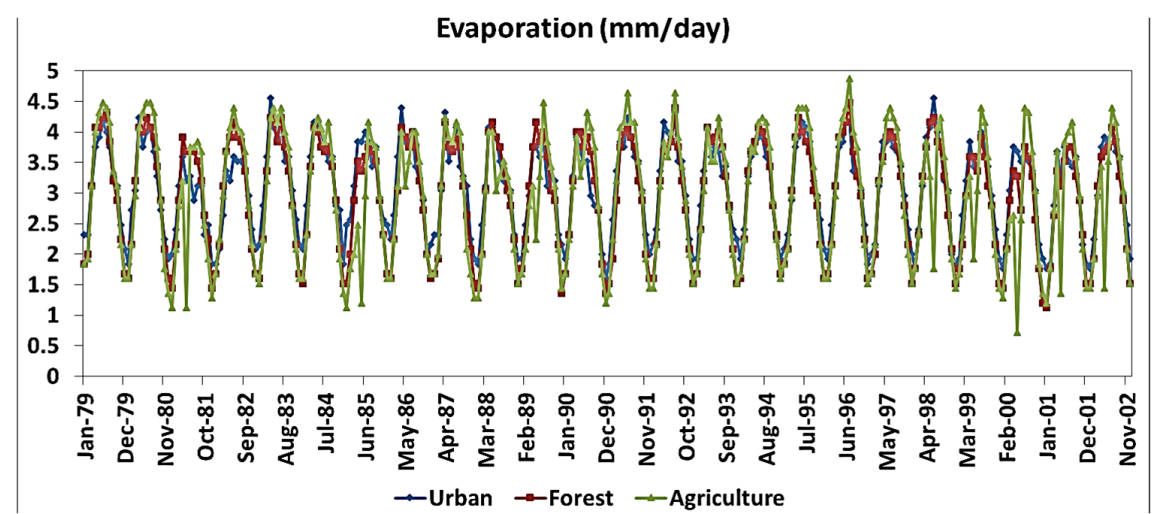

(a)

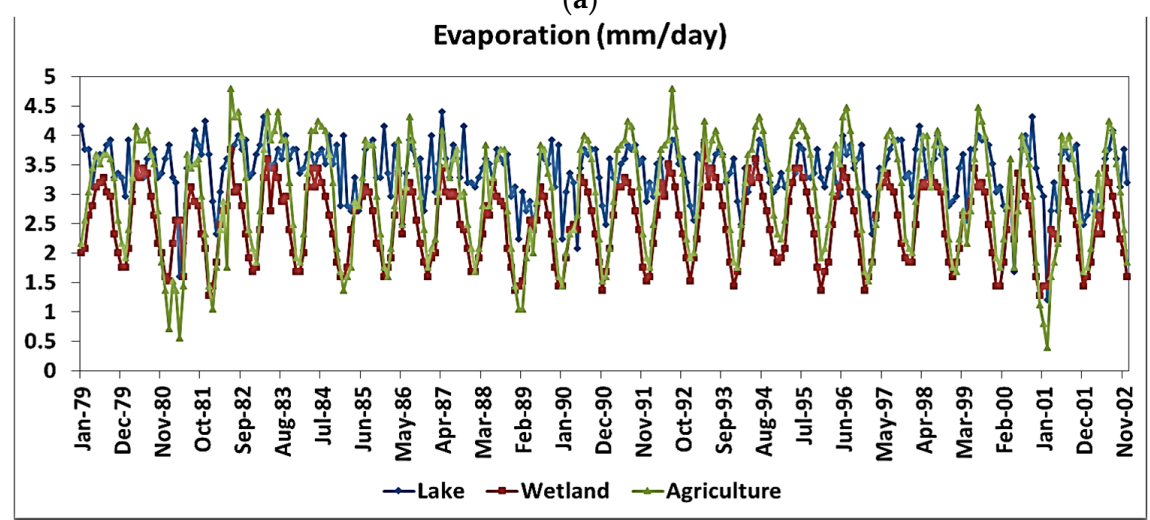

(b)

Figure 6. (a) Time series for monthly evaporation patterns for Northeast Florida; (b) Time series for monthly evaporation patterns for South Florida.

Soil moisture can reflect past precipitation, evaporation, infiltration, and runoff. In turn, the soil moisture acts as a strong control on the partitioning between sensible heat and latent heat fluxes at the surface, thus modulating precipitation over a given basin. Figure $7 \mathrm{a}, \mathrm{b}$ shows a range of 0-200 mm monthly soil moisture for agriculture, forest, and wetland areas in northeast and south Florida, respectively. The urban and lake areas were not evaluated because monthly soil moisture reanalysis data were not available. The soil moisture ranged from $122 \mathrm{~mm}$ to $561 \mathrm{~mm}$ on the forest and agriculture areas in northeast, while in the south, it ranged from $261 \mathrm{~mm}$ to $706 \mathrm{~mm}$ on the 
wetland and agriculture areas. Table 1 presents the mean rainfall and evaporation from 1979 to 2002 on the study area, thus suggesting that the wetland areas had the lowest average value of evaporation. In the northeast, the urban area located around St. John's River had higher evaporation as most of rainfall was returned to the atmosphere locally by evaporation; hence the ratio of evaporation/rainfall (E/P) was almost unity. According to Romero's report, they calculated average yearly reference evapotranspiration $\left(\mathrm{ET}_{\mathrm{o}}\right)$ and rainfall for the 30-year period (1980-2009) of weather station data records in Jacksonville [39]. They found out the average yearly $\mathrm{ET}_{\mathrm{o}}$ in Jacksonville was $52.2 \mathrm{in} /$ year, and rainfall was $53.4 \mathrm{in} /$ year. Hence, the ratio of $\mathrm{E} / \mathrm{P}$ was almost unity, which is also consistent with the NARR dataset's results.

Table 1. Annual Mean (1979-2002) Rainfall and Evaporation for the Various Land Uses in Florida.

\begin{tabular}{cccc}
\hline 1979-2002 Monthly Average & Rainfall (P) (mm/day) & Evaporation (E) (mm/day) & E/P \\
\hline Urban & 3.10 & 3.09 & 1.00 \\
Forest & 3.43 & 2.98 & 0.87 \\
Northeast Agriculture & 3.39 & 2.96 & 0.87 \\
Lake & 3.02 & 3.40 & 1.13 \\
Wetland & 3.54 & 2.51 & 0.71 \\
South Agriculture & 3.18 & 2.97 & 0.93 \\
\hline
\end{tabular}

The forest area had higher rainfall and evaporation than the agriculture area because forests could maintain more soil moisture for evaporation, which results in higher rainfall and lower runoff. In the south, evaporation loss in the lake area exceeded the amount of water gained from rainfall. Thus, the $\mathrm{E} / \mathrm{P}$ is higher than unity. These results showed the annual evaporation rate for Lake Okeechobee area as between 3.45 to $3.54 \mathrm{~mm}$ /day are comparable to those found by the previous studies with evaporation obtained from in situ measurements [40].

Soil Moisture (0-200mm)

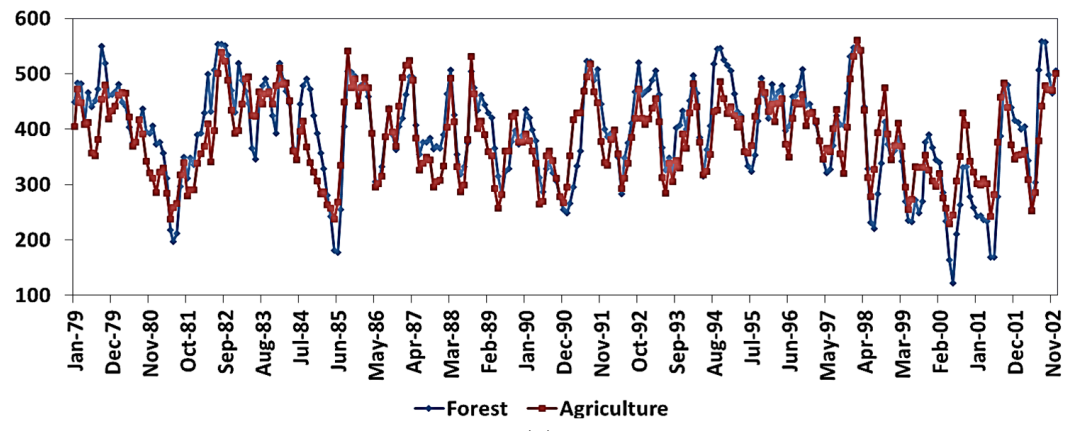

(a)

Soil Moisture (0-200 $\mathrm{mm})$

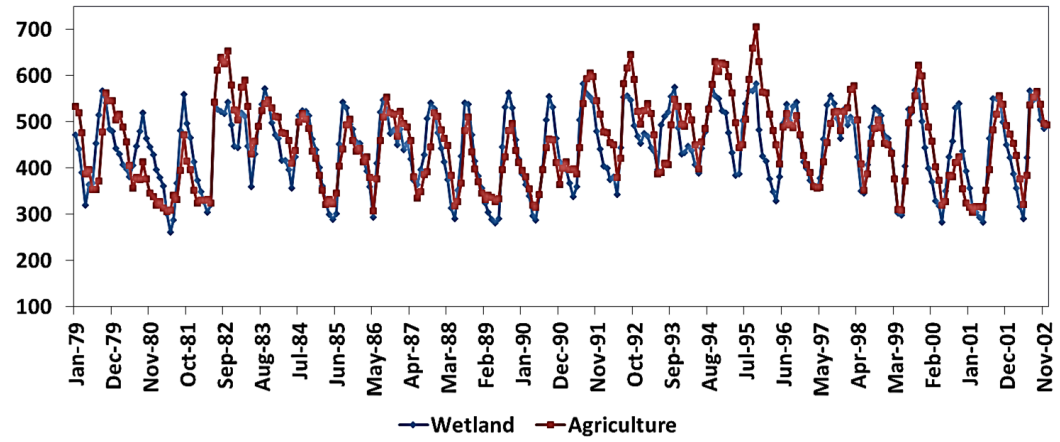

(b)

Figure 7. (a) Time series monthly soil moisture $(0-200 \mathrm{~mm})$ patterns for Northeast Florida; (b) Time series monthly soil moisture $(0-200 \mathrm{~mm})$ patterns for South Florida. 


\subsection{Monthly Bowen Ratio Variations}

In this study, latent heat and sensible heat fluxes were derived from the NARR datasets so that Bowen ratio could be obtained. Figure $8 \mathrm{a}$, b shows the inter-annual variations of monthly Bowen ratio in both study areas. In the northeast, the monthly Bowen ratio ranged from 0.18 to 0.8 over the urban areas, from 0.22 to 1.21 for the forest areas, and from 0.17 to 7.7 for the agriculture areas. In the south, the values ranged from 0.11 to 1.82 on the lake areas, from 0.33 to 2.33 on the wetland areas, and from 0.11 to 9.41 on the agriculture areas. From Table 2, we found that Bowen ratio could be used to reflect or identify different land use characteristics. For example, the lake and urban areas had lower Bowen ratio because more surface energy would be partitioned into latent heat for evaporation, while the wetland areas had higher Bowen ratio value because of lower evaporation value. The Bowen ratio on the forest and agriculture areas ranged from 0.49 to 0.6. Figure $9 a, b$ shows the Bowen ratio map over Florida during April and May 1996, respectively, suggesting that at no drought events, Bowen ratio was lower over Florida. However, during drought events (April 2000 and May 2001), west Florida areas with agriculture and urban land uses (see Figure 3) had higher Bowen ratio as shown in Figure 10a,b. It is suggested that because agriculture areas have lower ET and soil moisture, most of the surface energy would be partitioned into sensible heat. Therefore, Bowen ratio is higher during drought conditions, and the ratio could be used as an indicator to monitor drought events and land use response.

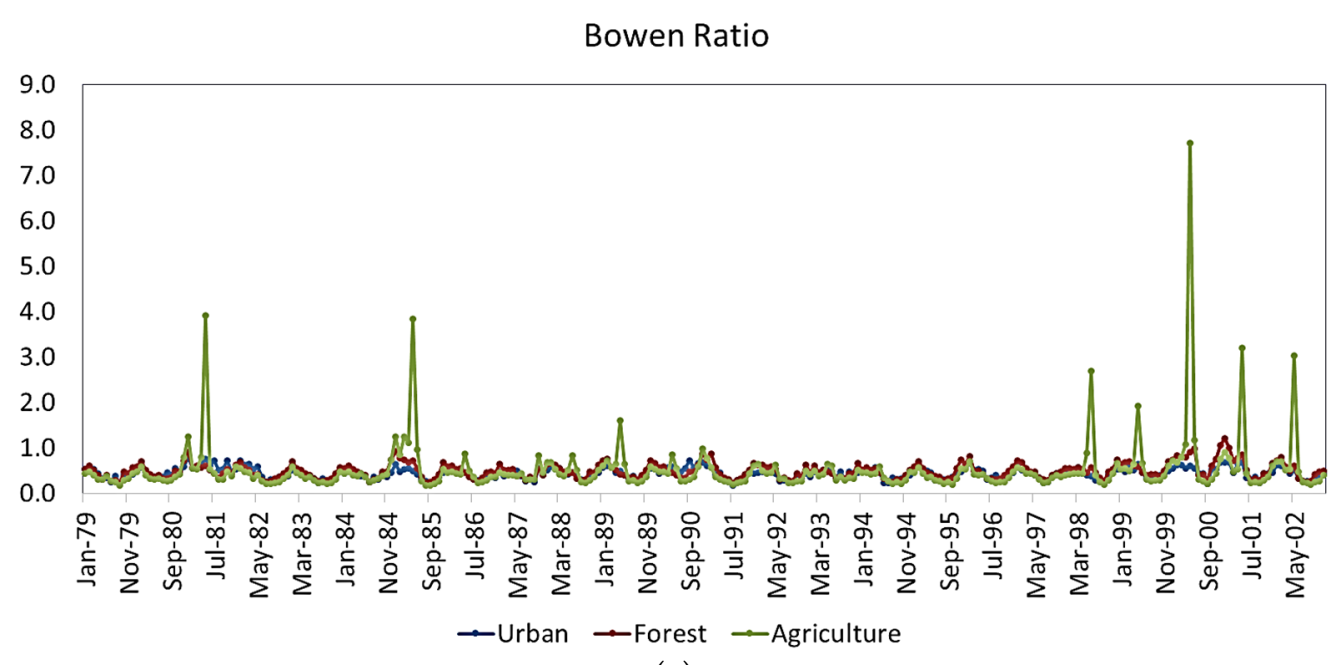

(a)

Bowen Ratio

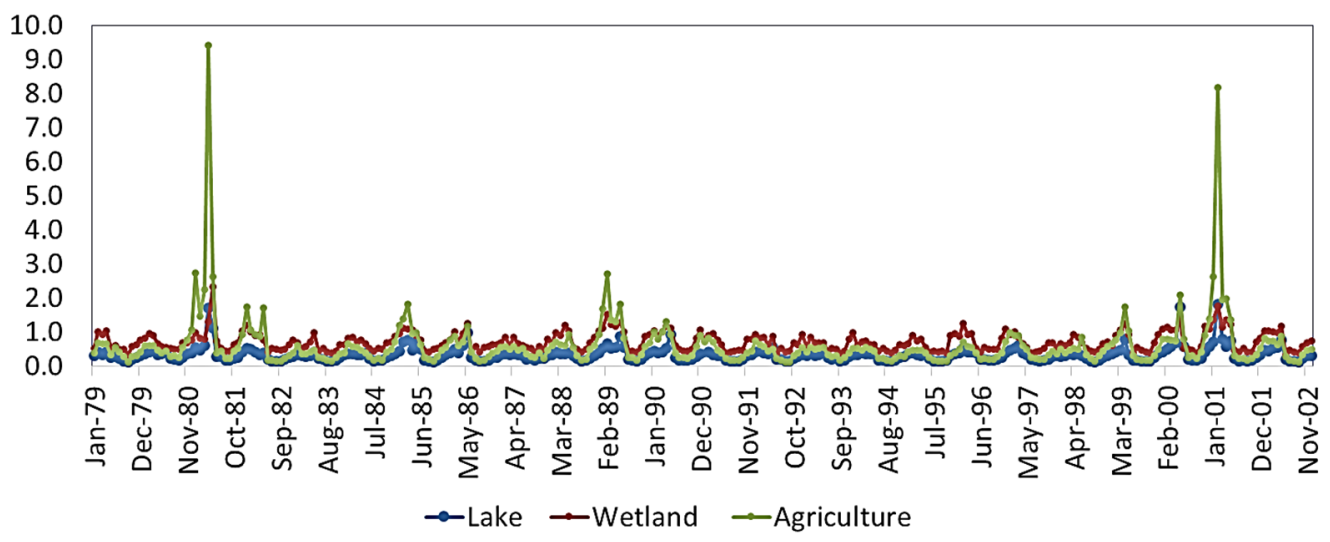

(b)

Figure 8. (a) Time Series for Monthly Bowen Ratio Patterns for Northeast Florida; (b) Time Series for Monthly Bowen Ratio Patterns for South Florida. 
Table 2. Annual Mean (1979-2002) Bowen Ratio for the Various Land Uses in Florida.

\begin{tabular}{cc}
\hline 1979-2002 Monthly Average & Bowen Ratio \\
\hline Urban & 0.44 \\
Forest & 0.49 \\
Northeast Agriculture & 0.51 \\
Lake & 0.33 \\
Wetland & 0.71 \\
South Agriculture & 0.60 \\
\hline
\end{tabular}

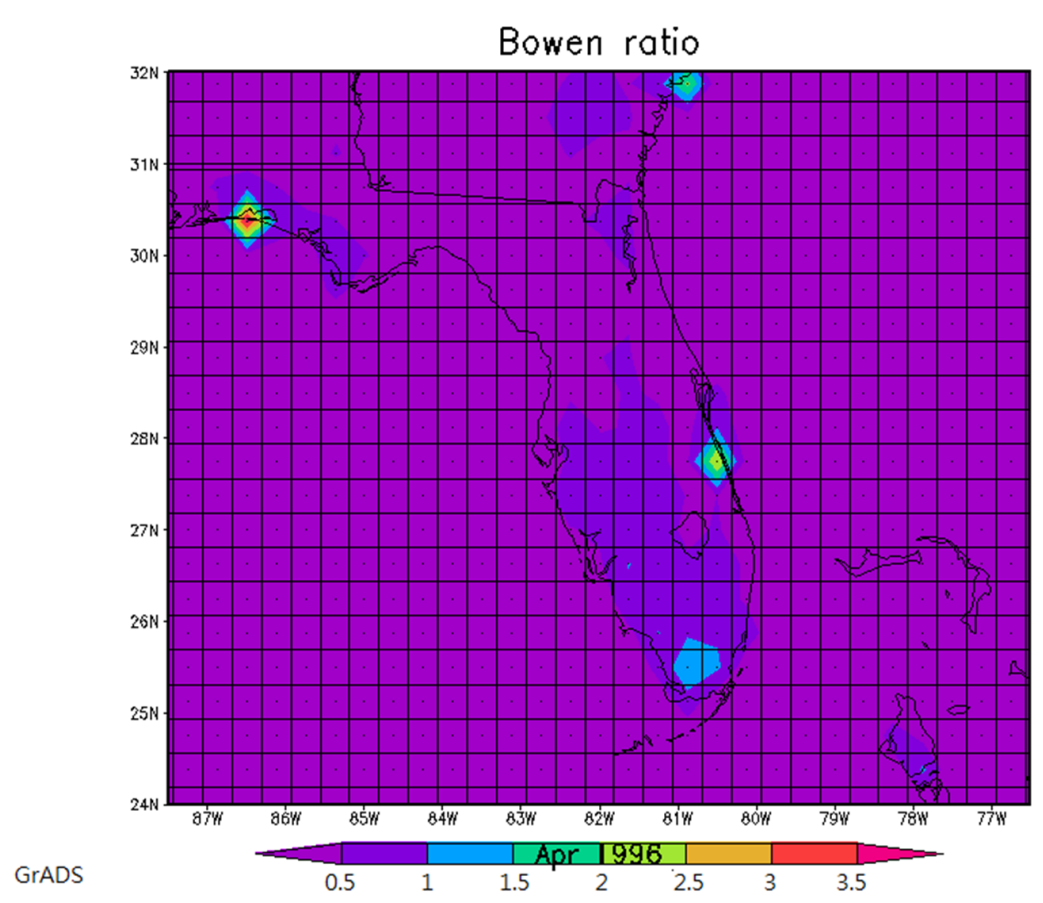

(a)

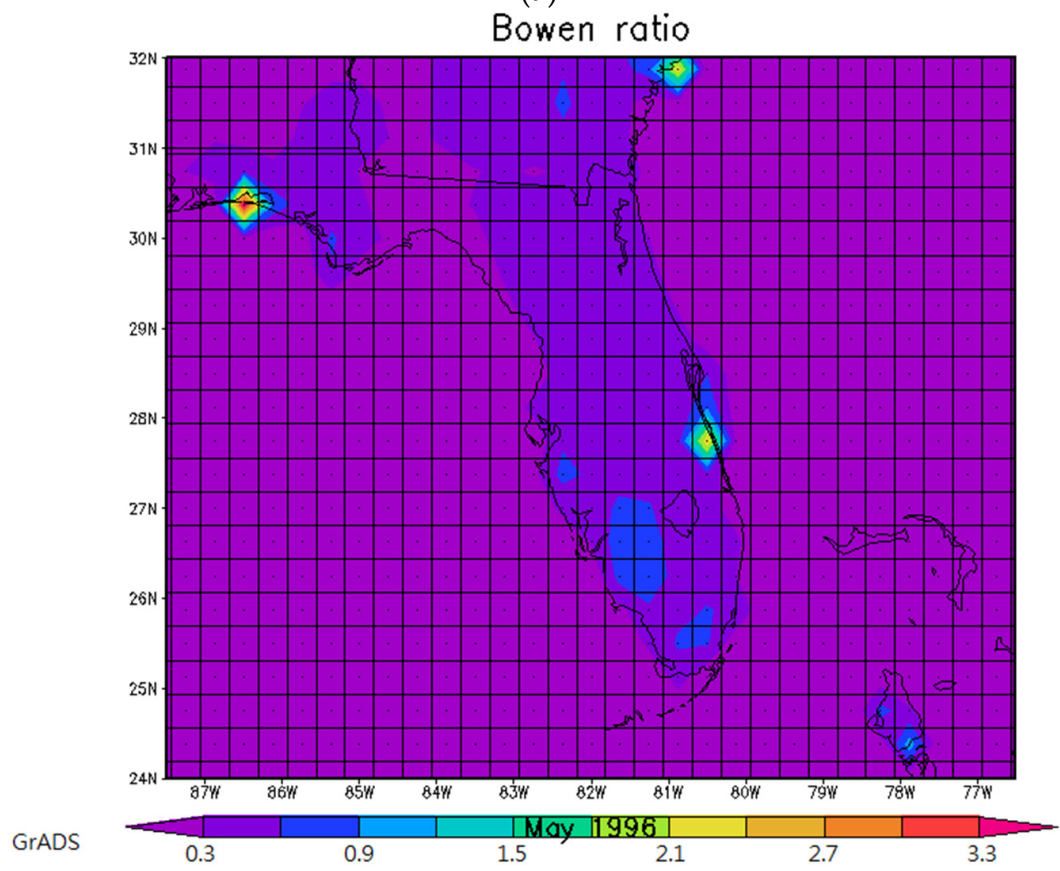

(b)

Figure 9. (a,b) Maps of Bowen Ratio in (a) April and (b) May 1996 over Florida. 


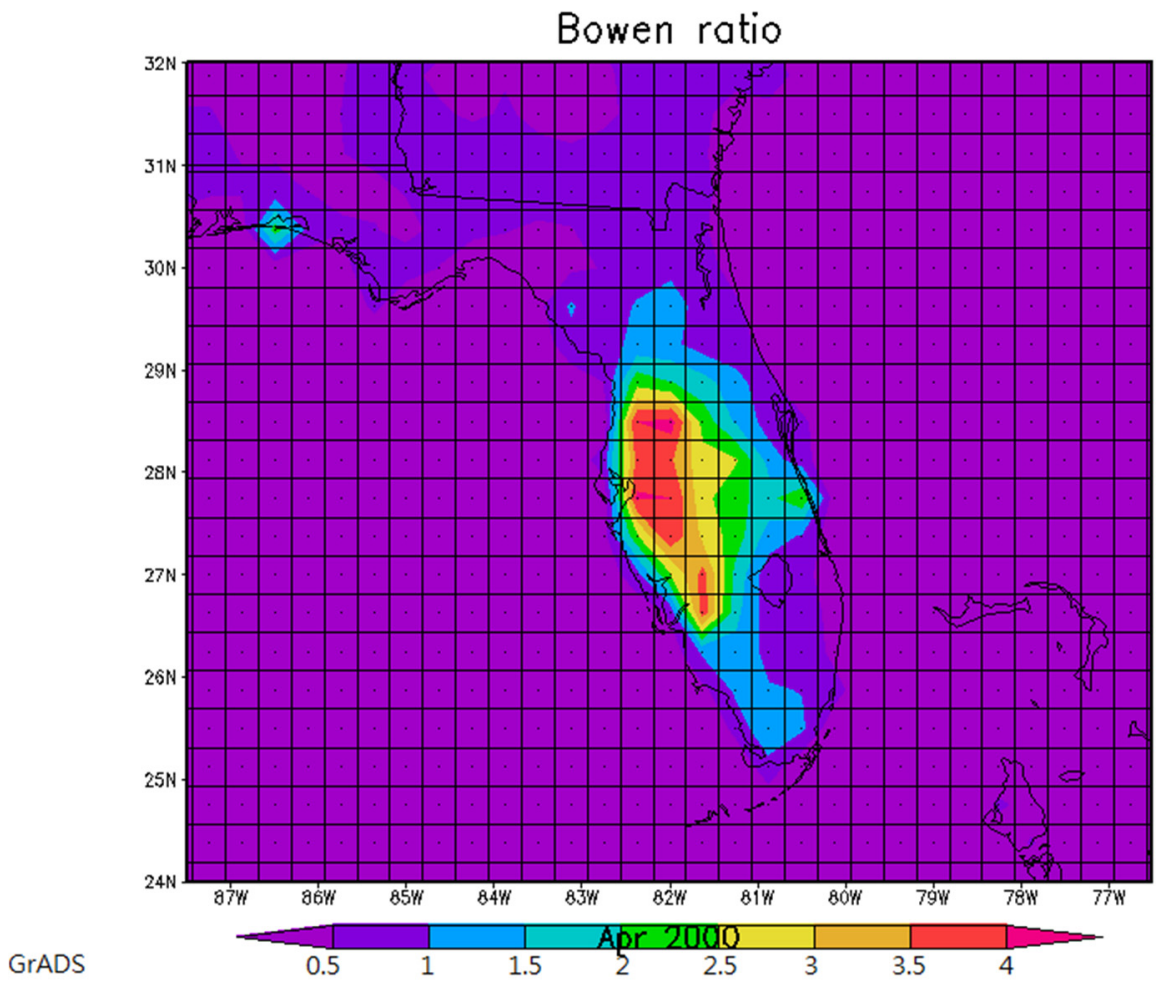

(a)

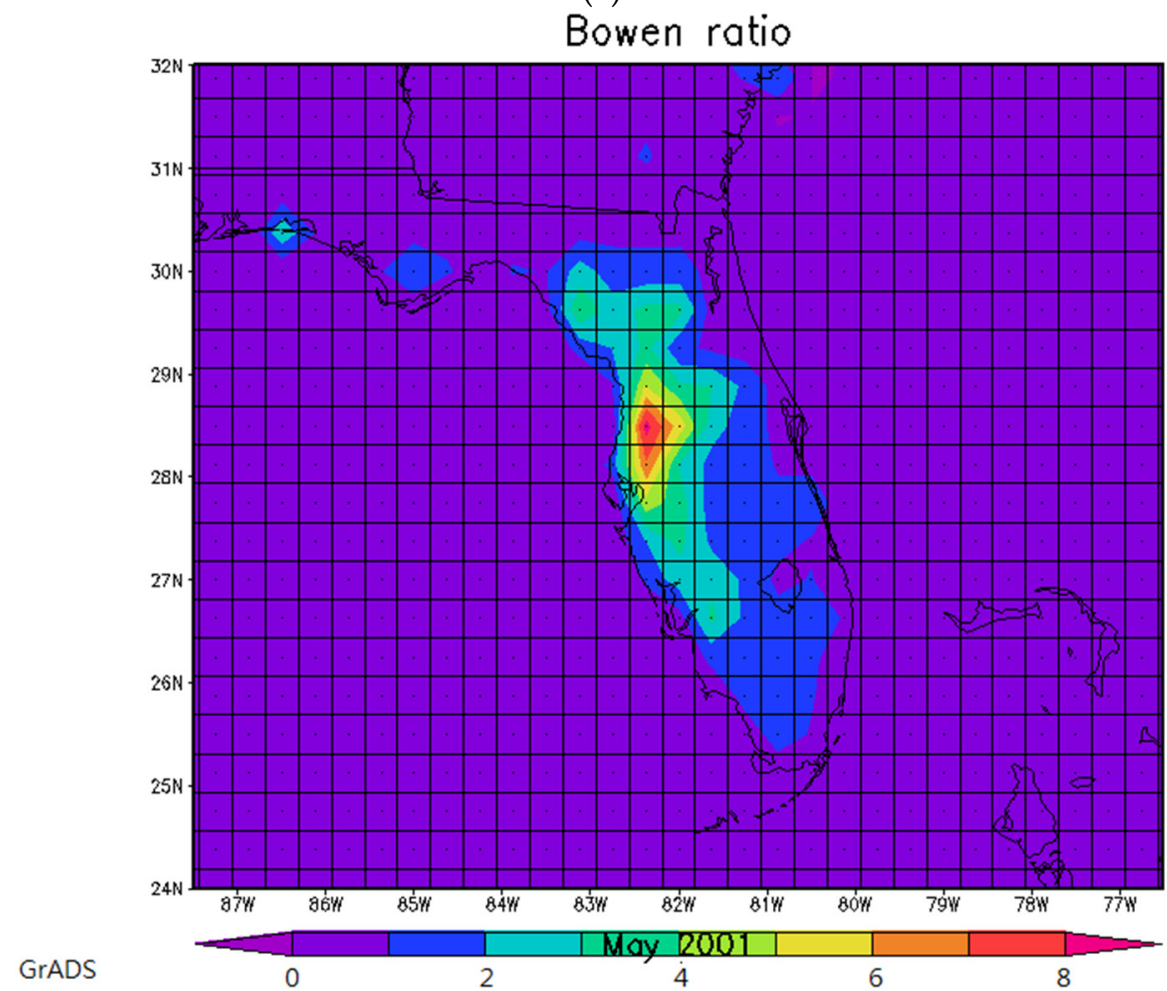

(b)

Figure 10. (a,b) Maps of Bowen Ratio in (a) April 2000 and (b) May 2001 over Florida.

\subsection{Regional Land Use Adapted Drought Index (RLDI)}

A RLDI was calculated as the normalized monthly Bowen ratio for various land use areas. Figure 11 shows the time series plots of RLDI of the study areas, suggesting higher values 
happened during drought periods and reflecting the land use response to drought. To classify drought severity, the monthly RLDI values and monthly evaporation and rainfall were sorted and compared. Figure 12a,b shows the relationships between the sorted RLDI and evaporation and rainfall, respectively, thus suggesting higher RLDI with lower evaporation and rainfall and vice versa. When the RLDI value is greater than unity, evaporation and rainfall were extremely low. On the other hand, for RLDI values smaller than -0.5 , the evaporation and rainfall were extremely high. Hence, we classified RLDI into four different categories, including extreme drought, moderate drought, non-drought, and extreme wet. The extreme drought condition would have a RLDI value of 1 or greater, whereas an extreme wet condition would be -0.5 or less (Table 3). Figure 13a,b shows extreme events on the study areas and period with the RLDI drought classification, thus validating RLDI scale. From the figures, during the extreme drought, the rainfall and evaporation were excessively low, ranging from $0.2 \mathrm{~mm} /$ day to $1.8 \mathrm{~mm} /$ day, while during the extreme wet condition, their values were drastically high, changing from $3.5 \mathrm{~mm} /$ day to $12.3 \mathrm{~mm}$ /day (see Table 3).

Table 3. The Classification of Regional Land Use Adapted Drought Index (RLDI).

\begin{tabular}{ccc}
\hline Drought Classes & Rainfall $(\mathbf{m m} /$ day) & Evaporation (mm/day) \\
\hline Extreme Drought $(\mathrm{RLDI} \geqslant 1)$ & 0.74 & 1.36 \\
Moderate drought $(0.5<\mathrm{RLDI}<1)$ & 1.37 & 2.29 \\
Extreme Wet $(\mathrm{RLDI} \leqslant-0.5)$ & 6.84 & 3.7 \\
Total average & 3.28 & 2.99 \\
\hline
\end{tabular}

Regional Land Use Drought Index

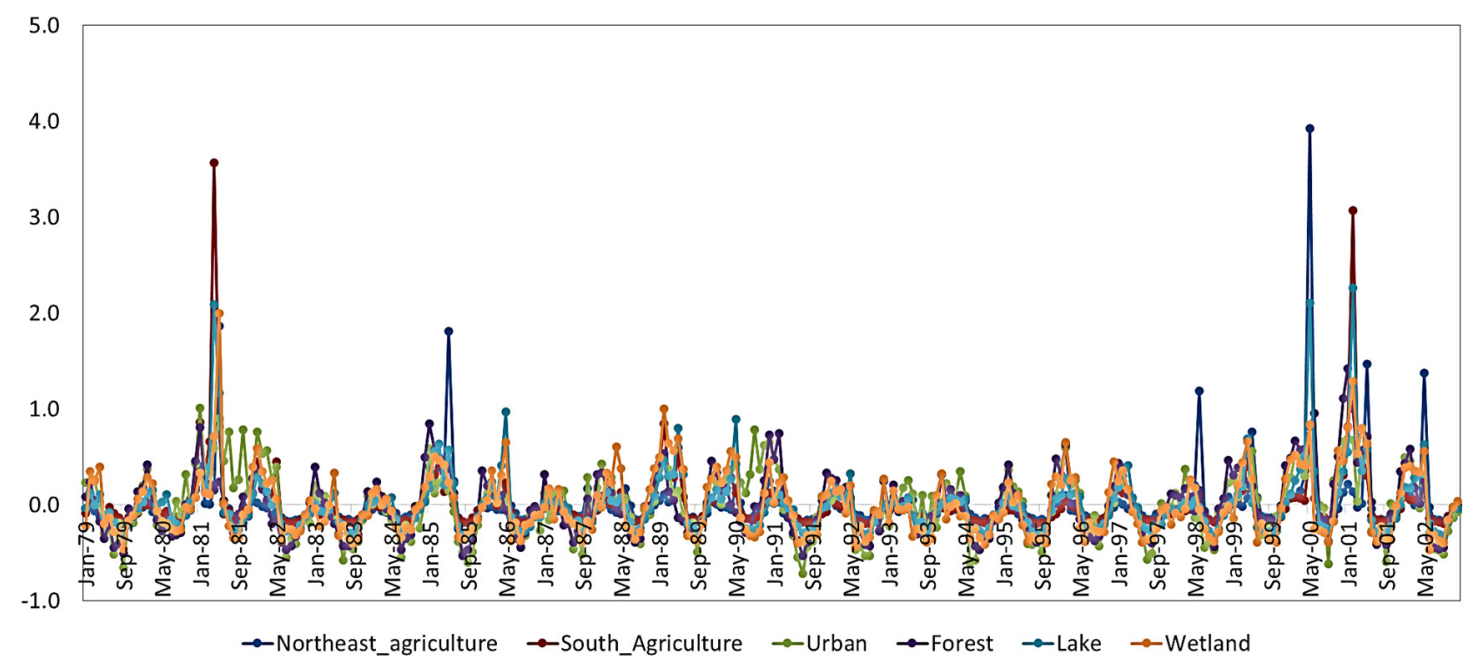

Figure 11. Time Series for Monthly RLDI in the Study Areas. 


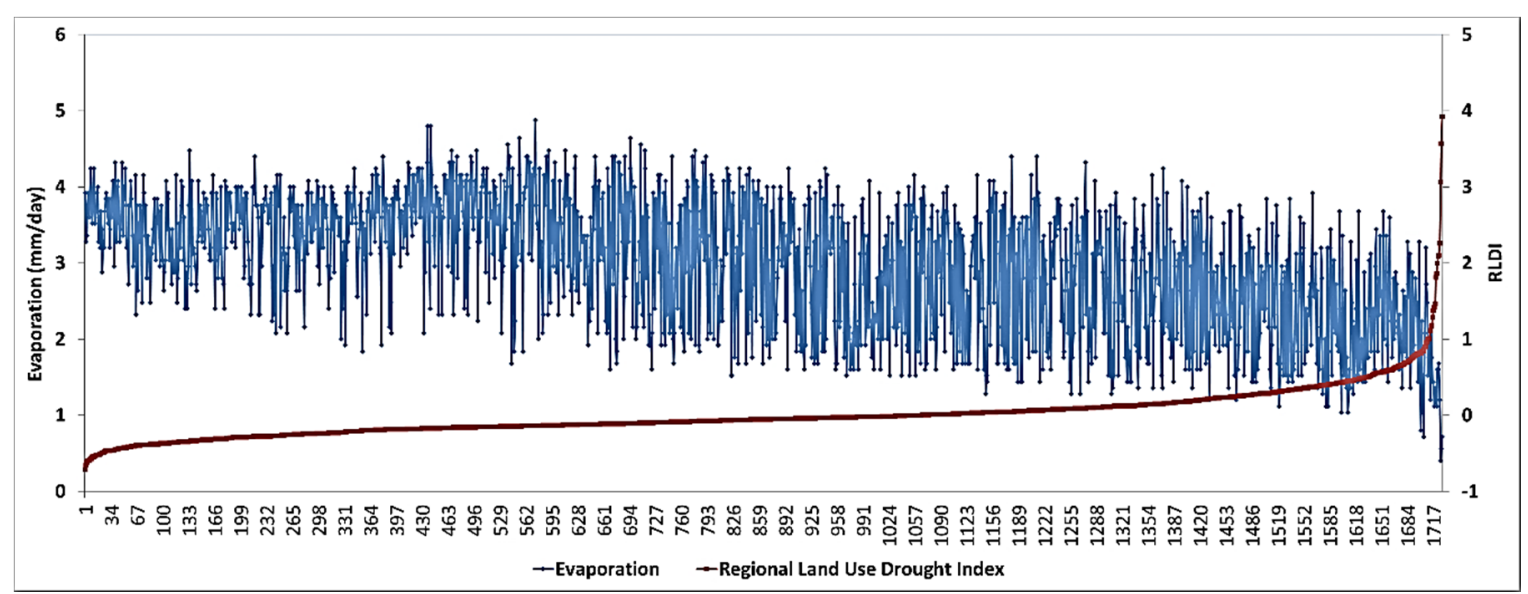

(a)

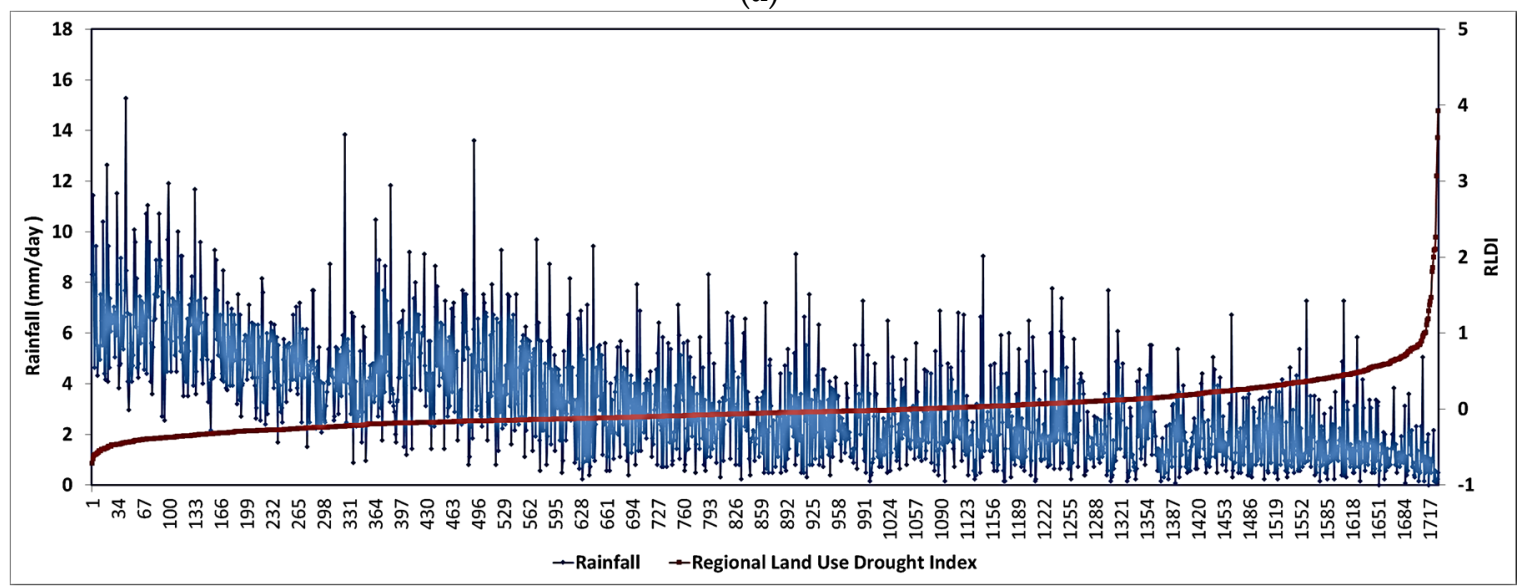

(b)

Figure 12. (a) Relationship between Sorted RLDI and Evaporation; (b) Relationship between Ordered RLDI and Rainfall.

\section{Extreme Drought}

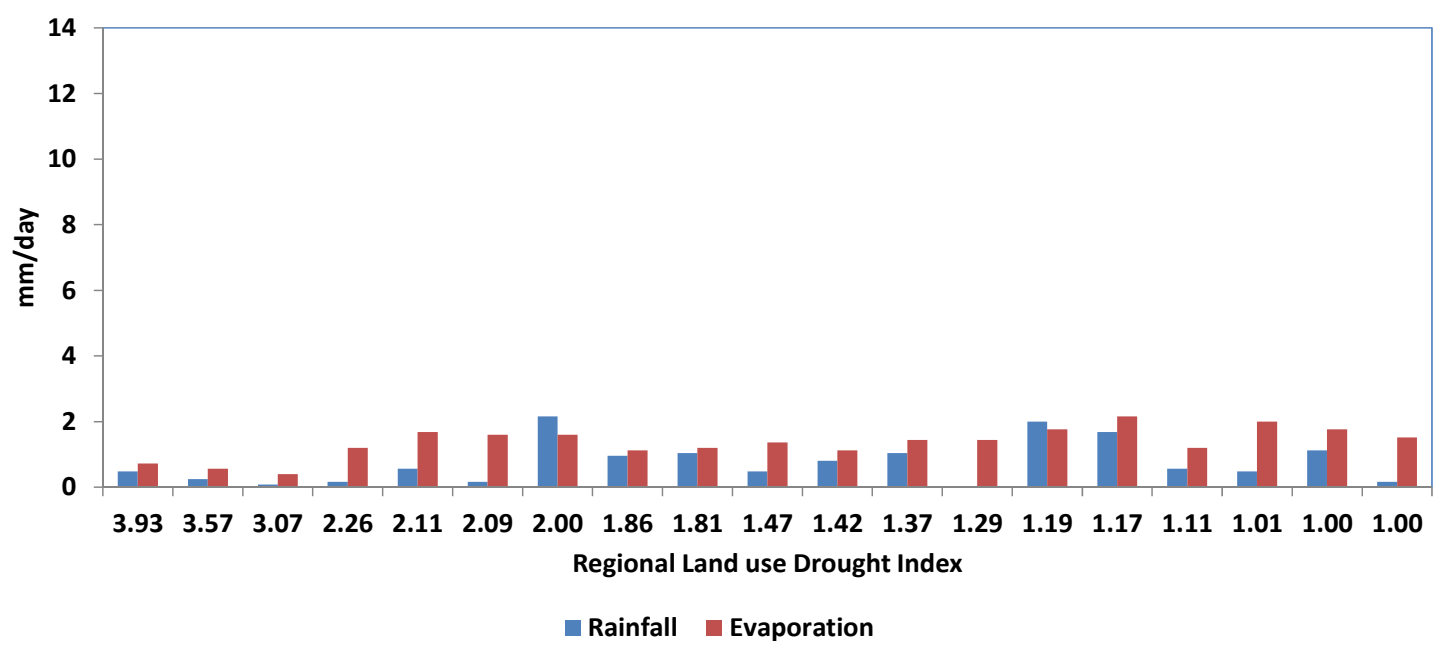

(a)

Figure 13. Cont. 


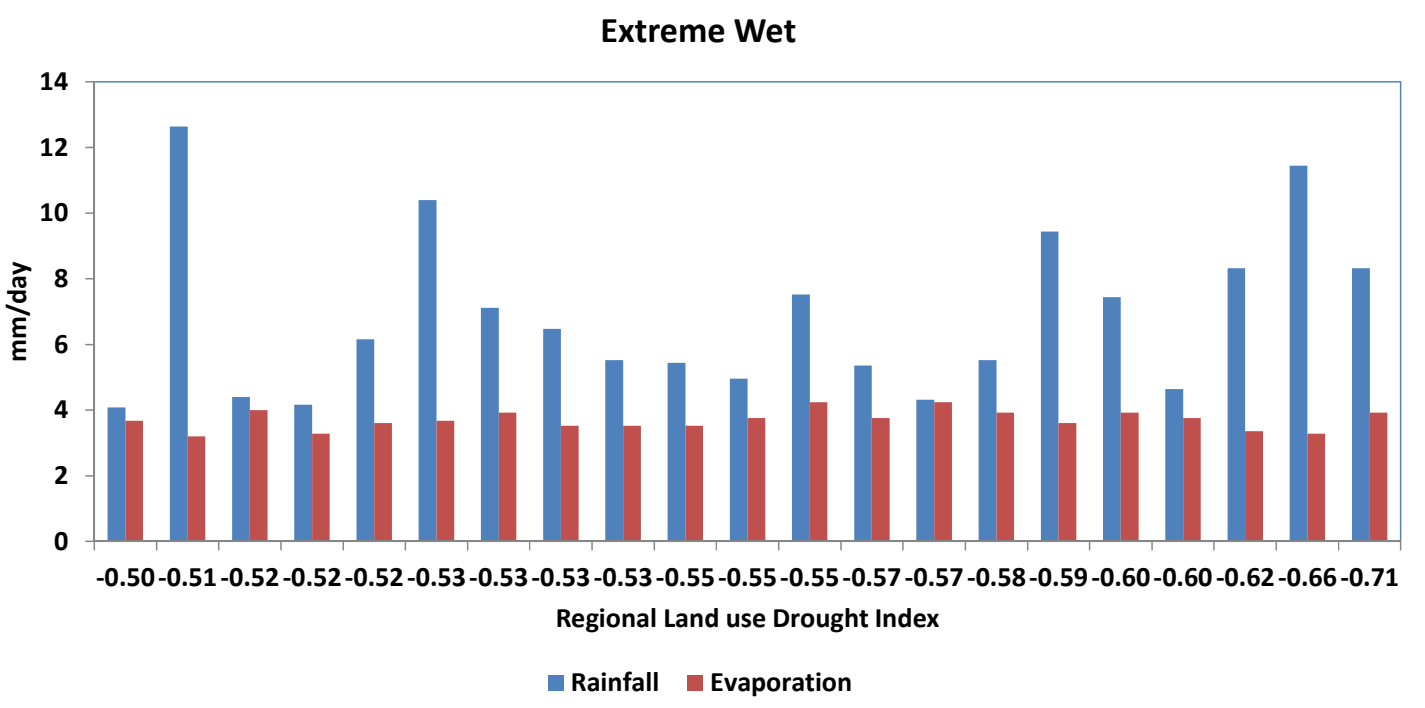

(b)

Figure 13. (a,b) Extreme Events and the RLDI Drought.

\subsection{Oceanic Niño Index (ONI) and RLDI}

The ONI, used for definitions of El Niño and La Niña conditions, was compared to the RLDI in Figure 14a through Figure 14c for the study period. In the ONI, low negative values indicated cold SST, and the ONI must exceed -0.5 for at least five consecutive months to be classified as La Niña episode. During the La Niña episodes of 1984-1985, 1988-1989, 1995-1996, and 1998-2000 in the study area, the RLDI values were higher, and during the drought events of 1981-1982 the ONI values were negative, which also resulted in higher RLDI values too. Hence, the RLDI can be a useful tool in ENSO forecast, agricultural planning, and water resource managements and can play a key role in mitigating the impacts of flood and drought.

Ocean Nino Index and RLDI

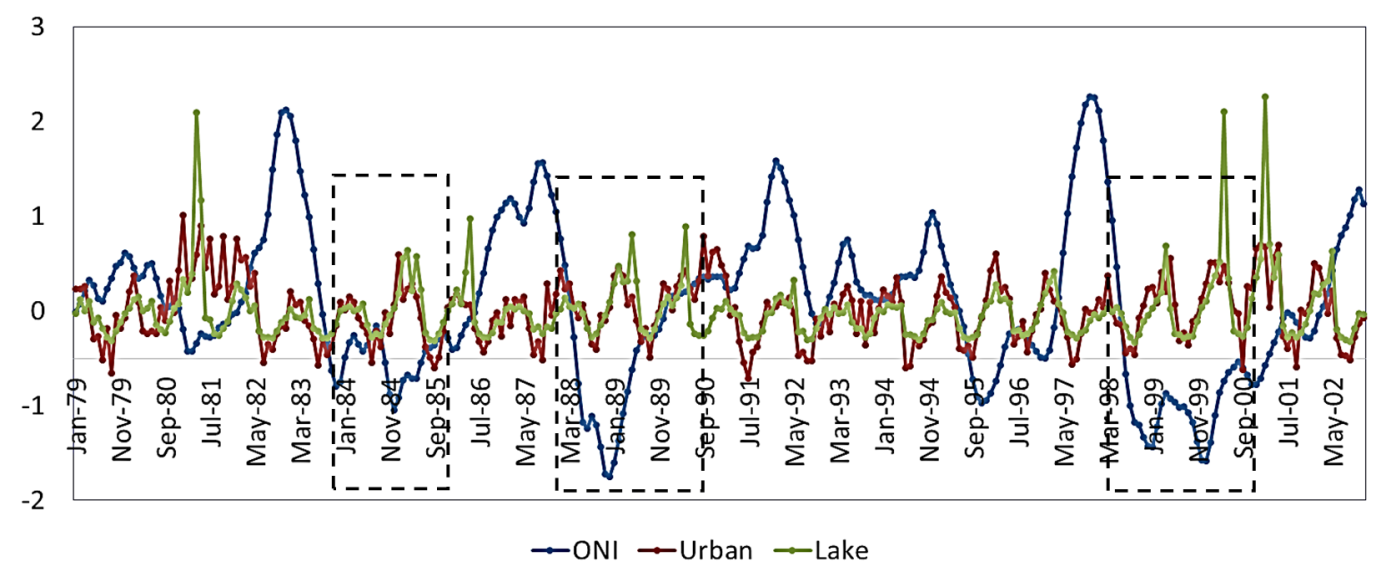

(a)

Figure 14. Cont. 


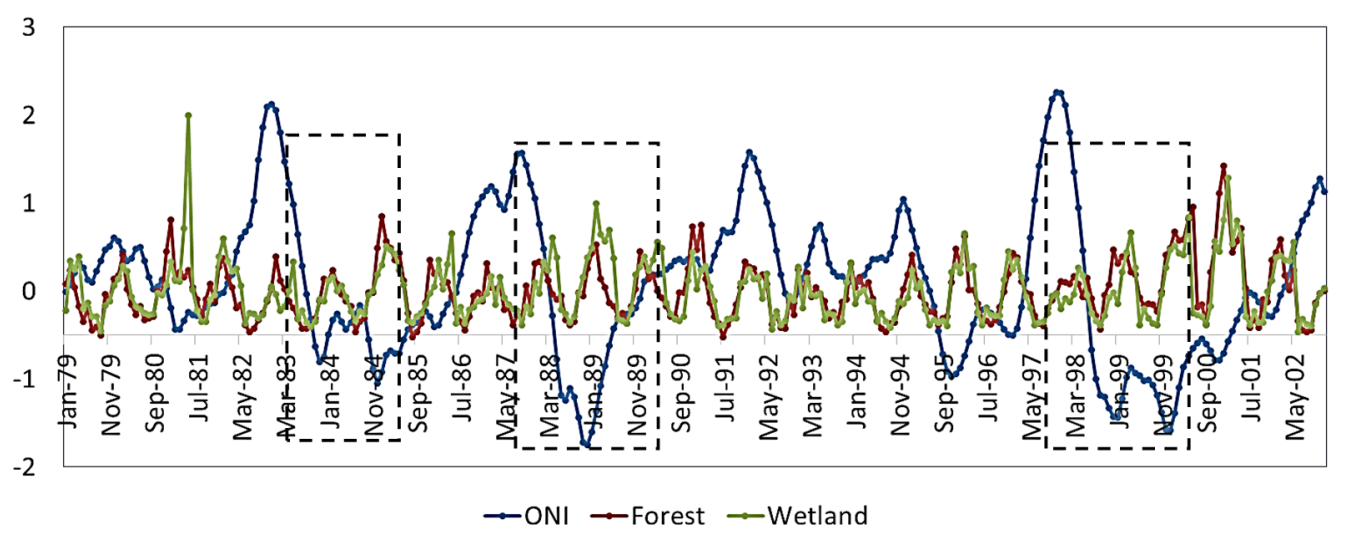

(b)

Ocean Nino Index and RLDI

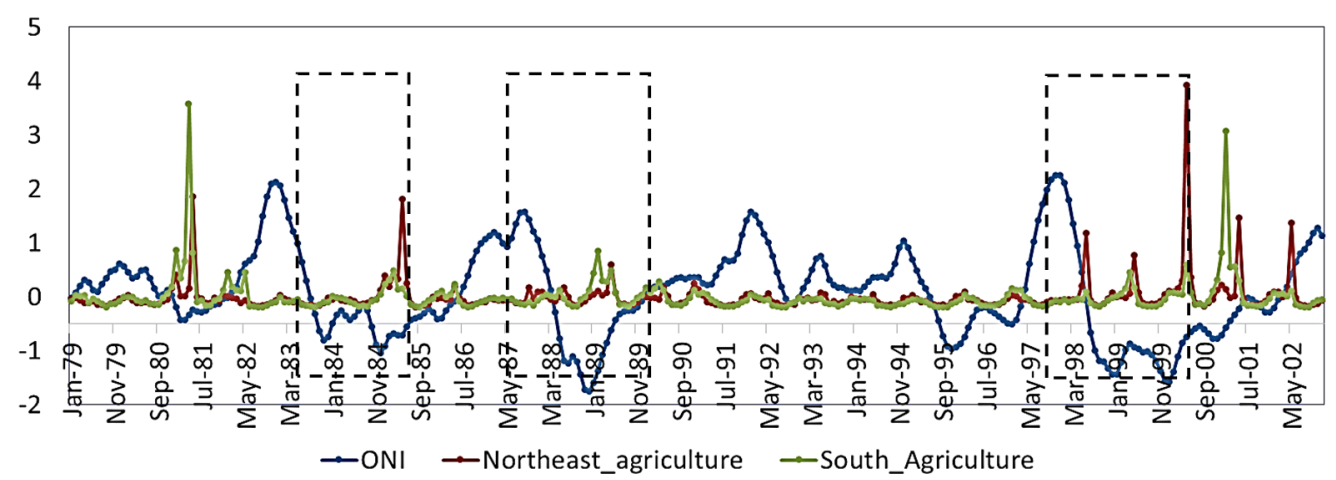

(c)

Figure 14. (a-c) Time Series Plots of ONI and RLDI; block boxes represent La Nina episodes.

\section{Uncertainties, Errors, and Accuracies}

In this study, we developed a new drought index to quality drought conditions on the different land use areas. The results demonstrated the new index could enable integration of land use/cover information into drought monitoring, and measure drought impacts on different land use types. If land use/cover condition is changed, altering water and energy budgets, the proposed drought index could be used to reassess the frequency and intensity of drought. By comparing the drought indexes before and after land use/cover change, the impacts of land use changes on droughts could be investigated. However, the limitations of the research are twofold: (1) We only applied the new index in the limited areas. To test robustness of the drought index, we need to apply this method for various climate conditions and land use/ cover types; (2) There is a limited accuracy in the energy flux data. The Bowen ratio was used as an indicator of RLDI so that there is a need to test the uncertainty in factors contributing to variation of Bowen ration. However, most of reanalysis dataset that we used were prepared with more attentions on precipitation assimilations. The uncertainties of Bowen ratio due to changes in climate and land use conditions were not examined in this study. Hence, more data would be needed to test the uncertainties of Bowen ratio and the new drought index in the future.

\section{Summary and Conclusions}

A RLDI was developed for the State of Florida based on NARR dataset from 1979 to 2002. The 24-year monthly data for precipitation, evaporation, soil moisture, and latent heat and sensible heat fluxes were analyzed for five different land uses (lake, urban, forest, wetland, and agriculture) in both northeast and south areas in Florida. The SPI was calculated to identify and validate the reported drought events. The results showed that the study areas experienced drier conditions during 
1980 to $1982,1984-1985,1988-1990$, and 1999-2001 periods. The intensive, short-term drought events occurred due to extreme deficits in rainfall in winter and early spring.

The analyses suggested that different land use types are strongly affected by evaporation and therefore had different responses to the drought events. The agriculture area had lower evaporation rates in spring, while, the forest, urban, wetland, and open water areas, had higher values. Previous studies suggested that evaporation rate measurement at Lake Okeechobee was difficult, but the NARR dataset provided a valuable resource for estimating evaporation rate over water bodies.

The Bowen ratio was used as an indicator to monitor drought events. The results showed that the lake and urban areas had lower Bowen ratio, while the wetland areas had higher values because of the lowest value of evaporation. The land use response to Bowen ratio was due to the soil moisture acting as a strong control on the partitioning between sensible heat and latent heat fluxes at the surface that in turn affects the surface temperature and evaporation rate.

A RLDI was calculated based on normalized monthly Bowen ratio for various land use areas. Drought severity was evaluated and the results showed that when the values of RLDI were larger than unity, the evaporation and rainfall were extremely low. While for values smaller than -0.5 , the evaporation and rainfall were extremely high. The RLDI approach gave a unique opportunity to predict and correlate drought events with rainfall, evaporation, and soil moisture, and also evaluates the land use response to drought conditions. RLDI can also be helpful to understand the local ENSO patterns on regional scale and reflect the level of severity in drought events resulting from land use effect. In summary, the advantages of RLDI were at least fourfold: (a) it reflects relationships among precipitation, evaporation, and soil moisture; (b) it reflects land use effects; (c) it links energy and water budgets; and (d) it can be easily calculated. In the future studies, the proposed new index may help scientists answer the critical questions about the drought effect on various land uses and the potential feedbacks of changes in land use and land cover to climate.

Acknowledgments: This research was partially supported by research grants MOST 103-2111-M-008-023 and 103-2221-E-008-074. The authors would like to thank the National Centers for Environmental Prediction (NCEP) for providing the North American Regional Reanalysis (NARR) data used in this study.

Author Contributions: The main idea of the paper arose from a discussion among the authors. Chi-Han Cheng conducted the data acquisition, processing, and analysis. Chi-Han Cheng wrote the paper. Fidelia Nnadi and Yuei-An Liou provided general advice. Yuei-An Liou made revisions and finalized the paper.

Conflicts of Interest: The authors declare no conflict of interest.

\section{References}

1. Nalbantis, I.; Tsakiris, G. Assessment of hydrological drought revisited. Water Resour. Manag. 2009, 23, 881-897. [CrossRef]

2. Federal Emergency Management Agency, Mitigation Directorate. The 1993 and 1995 Mid-west Floods: Flood Hazard Mitigation through Property Hazard Acquisition and Relocation Program; FEMA Mitigation Directorate: Washington, DC, USA, 1995.

3. Wilhite, D.A. Drought as a natural hazard: Concepts and definitions. In Drought: A Global Assessment; Routledge: New York, NY, USA, 2000; Volume 1, pp. 3-18.

4. Palmer, W.C. Meteorological Drought; Weather Bureau Research Paper 45; U.S. Department of Commerce: Washington, DC, USA, 1965.

5. Palmer, W.C. Keeping track of crop moisture conditions, nationwide: The new crop moisture index. Weatherwise 1968, 21, 156-161. [CrossRef]

6. McKee, T.B.; Doesken, N.J.; Kleist, J. The relationship of drought frequency and duration to time scales. In Proceedings of the Eighth Conference on Applied Climatology, Anaheim, CA, USA, 17-22 January 1993; American Meteorological Society: Boston, MA, USA, 1993; pp. 179-184.

7. Shafer, B.A.; Dezman, L.E. Development of a Surface Water Supply Index (SWSI) to assess the severity of drought conditions in snowpack runoff areas. In Proceedings of the 50th Annual Western Snow Conference, Reno, NV, USA, 19-23 April 1982; Colorado State University: Fort Collins, CO, USA, 1982; pp. 164-175. 
8. Thornthwaite, C.W. An approach toward a rational classification of climate. Geogr. Rev. 1948, 38, 55-94. [CrossRef]

9. Jensen, M.E.; Burman, R.D.; Allen, R.G. Evapotranspiration and Irrigation Water Requirements; ASCE Manuals and Reports on Engineering Practice; American Society of Civil Engineers: New York, NY, USA, 1990.

10. Abramopoulos, F.; Rosenzweig, C.; Choudhury, B. Improved ground hydrology calculations for global climate models (GCMs): Soil water movement and evapotranspiration. J. Clim. 1988, 1, 921-941. [CrossRef]

11. Kim, D.; Hi-ryong, B.; Ki-seon, C. Evaluation, modification, and application of the Effective Drought Index to 200-Year drought climatology of Seoul, Korea. J. Hydrol. 2009, 378, 1-12. [CrossRef]

12. Narasimhan, B.; Srinivasan, R. Development and evaluation of Soil Moisture Deficit Index (SMDI) and Evapotranspiration Deficit Index (ETDI) for agricultural drought monitoring. Agric. For. Meteorol. 2005, 133, 69-88. [CrossRef]

13. Tsakiris, G.; Vangelis, H. Establishing a drought index incorporating evapotranspiration. Eur. Water 2005, 9, 3-11.

14. Keyantash, J.A.; Dracup, J.A. An aggregate drought index: Assessing drought severity based on fluctuations in the hydrologic cycle and surface water storage. Water Resour. 2004, 40,1-14. [CrossRef]

15. Pan, M.; Wood, E.F. Data Assimilation for estimating the terrestrial water budget using a constrained ensemble kalman filter. J. Hydrometeorol. 2006, 7, 534-547. [CrossRef]

16. Luo, Y.; Ernesto, H.B.; Kenneth, E.M. The operational ETA model precipitation and surface hydrologic cycle of the Columbia and Colorado Basins. J. Hydrometeorol. 2005, 6, 341-370. [CrossRef]

17. Findell, K.; LShevliakova, E. Modeled impact of anthropogenic land cover change on climate. J. Clim. 2007, 20, 3621-3634. [CrossRef]

18. Ek, M.B.; Mitchell, K.E.; Lin, Y.; Grunmann, P.; Rogers, E.; Gayno, G.; Koren, V.; Tarpley, J.D. Implementation of Noah land surface model advances in the National Centers for Environmental Prediction operational mesoscale Eta model. J. Geophys. Res. 2003, 108. [CrossRef]

19. Mitchell, K. NCEP completes 25-year North American Reanalysis: Precipitation assimilation and land surface are two hallmarks. GEWEX News 2004, 14, 9-12.

20. Kumar, V.; Panu, U. Predictive assessment of severity of agricultural droughts based on agro-climatic factors. J. Am. Water Resour. Assoc. 1997, 33, 1255-1264. [CrossRef]

21. Diffenbaugh, N.S.; Giorgi, F.; Pal, J.S. Climate change hotspots in the United States. Geophys. Res. Lett. 2008, 35. [CrossRef]

22. Dominguez, F.; Kumar, P.; Vivoni, E.R. Precipitation recycling variability and ecoclimatological stability-A study using NARR data. Part II: North American Monsoon Region. J. Clim. 2008, 21, 5187-5203. [CrossRef]

23. Fall, S.; Niyogi, D.; Gluhovsky, A.; Pielke, R.A.; Kalnay, E.; Rochon, G. Impacts of land use land cover on temperature trends over the continental United States: Assessment using the North American Regional Reanalysis. Int. J. Climatol. 2010, 30, 1980-1993. [CrossRef]

24. Ropelewski, C.F.; Halpert, M.S. North American precipitation and temperature patterns associated with the El Nino Southern Oscillation (ENSO). Mon. Weather Rev. 1986, 114, 2352-2362. [CrossRef]

25. Kiladis, G.N.; Diaz, H.F. Global climatic anomalies associated with extremes in the Southern Oscillation. J. Clim. 1989, 2, 1069-1090. [CrossRef]

26. Hanson, K.; Maul, G.A. Florida precipitation and the Pacific El Niño, 1895-1989. Fla Sci. 1991, 54, $160-168$.

27. Sittel, M.C. Marginal Probabilities of the Extremes of ENSO Events for Temperature and Precipitation in the Southeastern United States; Center for Ocean-Atmospheric Studies, The Florida State University: Tallahassee, FL, USA, 1994.

28. Twine, T.E.; Christopher, J.K.; Jonathan, A.F. Effects of El Niño-Southern Oscillation on the climate, water balance, and stream-flow of the Mississippi River Basin. J. Clim. 2005, 18, 4840-4861. [CrossRef]

29. Douglas, A.; Englehart, P. On a statistical relationship between autumn rainfall in the central equatorial Pacific and subsequent winter precipitation in Florida. Mon. Weather Rev. 1981, 109, 2377-2382. [CrossRef]

30. Florida Agricultural Statistics Service. Florida Agriculture: Vegetables Winter Acreage; Florida Agricultural Statistics Service, Florida Department of Agriculture and Consumer Services: Tallahassee, FL, USA, 1996.

31. Florida Agricultural Statistics. Florida Agricultural Statistics: Vegetable Summary (1995-1996); Florida Agricultural Statistics Service, Florida Department of Agriculture and Consumer Services: Tallahassee, FL, USA, 1997. 
32. Mills, D.M. Climate change, extreme weather events, and us health impacts: What can we say? J. Occup. Environ. Med. 2009, 51, 26-32. [CrossRef] [PubMed]

33. Carter, D.R.; Jokela, E.J. Florida's Renewable Forest Resources; University of Florida Cooperative Extension Service, Institute of Food and Agricultural Sciences: Gainesville, FL, USA, 2002.

34. Cheng, C.H.; Nnadi, F.; Liou, Y.A. Energy budget on various land use areas using reanalysis data in Florida. Adv. Meteorol. 2014, 2014. [CrossRef]

35. Folks, J.C. Lake Okeechobee TMDL: Technologies and Research; North Carolina State University College of Agriculture and Life Sciences: Raleigh, NC, USA, 2005; pp. 1-12.

36. Snyder, G.H. Agricultural Flooding of Organic Soils; Bulletin No. 570; Institute of Food and Agricultural Sciences, University of Florida: Gainesville, FL, USA, 1987.

37. Drummond, M.A.; Loveland, T.R. Land-use pressure and a transition to forest-cover loss in the Eastern United States. Bioscience 2010, 60, 286-298. [CrossRef]

38. Knowles, L. Estimation of Evapotranspiration in the Rainbow Springs and Silver Springs Basins in North Central Florida; Technical Report for US Geological Survey, Water Resources Investigations Report 96-4024; U.S. Department of the Interior: Tallahassee, FL, USA, 1996.

39. Romero, C.C.; Dukes, M.D. Turfgrass and Ornamental Plant Evapotranspiration and Crop Coefficient Literature Review; Agricultural and Biological Engineering Department, University of Florida: Gainesville, FL, USA, 2009.

40. Viessman, W.; Klapp, J.W.; Lewis, G.L.; Harbaugh, T.E. Introduction to Hydrology; Harper and Row: New York, NY, USA, 1977.

(C) 2015 by the authors; licensee MDPI, Basel, Switzerland. This article is an open access article distributed under the terms and conditions of the Creative Commons by Attribution (CC-BY) license (http://creativecommons.org/licenses/by/4.0/). 